Vol.45, Special n. : pp. 69-81, September 2002

ISSN 1516-8913 Printed in Brazil

\title{
Scintigraphic Imaging of Focal Hypoxic Tissue: Development and Clinical Applications of ${ }^{123}$ I-IAZA
}

\author{
Leonard I. Wiebe* and Alexander J. B. McEwan \\ University of Alberta and Cross Cancer Institute; Edmonton; Canada
}

\begin{abstract}
Affected tissues in a number of diseases, including cancer, stroke, cardiac infarction and diabetes, develop focal tissue hypoxia during their progression. The presence of hypoxic tissue may make the disease refractory to therapy, as in the case of solid tumor therapy using low LET ionizing radiation. In other pathologies, the detection of viable but hypoxic tissues may serve as a prodromal indicator of developing disease (e.g. diabetes),or as a prognostic indicator for management of the disease (e.g. stroke). Over the past two decades, a number of hypoxia radioimaging agents have been developed and tested clinically. Of these, ${ }^{18}$ F-Fmiso and ${ }^{123}$ I-IAZA are the most widely used radiotracers for PET and SPECT/planar imaging, respectively. IAZA and Fmiso are a 2-nitroimidazoles that chemically bind to subcellular components of viable hypoxic tissues. They sensitize hypoxic tumour to the killing effects of ionizing radiation via mechanisms that mimic the radiosensitizing effects of oxygen, and are therefore called oxygen mimetics. The oxygen mimetic effect is attributable in large part to the covalent binding of reductively-activated nitroimidazole intermediates to critical cellular macromolecules. Nitroimidazoles labelled with gamma-emitting radionuclides (e.g. ${ }^{18}$ F-Fmiso and ${ }^{123}$ I-IAZA) have been used as scintigraphic markers of tumour hypoxia, based on the need to identify radioresistant hypoxic tumour cells as part of the radiotherapy planning process. Broader interest in non-invasive, imaging-based identification of focal hypoxia in a number of diseases has extended hypoxia studies to include peripheral vascular disease associated with diabetes, rheumatoid arthritis, stroke, myocardial ischaemia, brain trauma and oxidative stress. In this review, the current status of hypoxia-selective studies with ${ }^{123}$ I-IAZA, an experimental diagnostic radiopharmaceutical, is reviewed with respect to its pre-clinical development and clinical applications.
\end{abstract}

Key words: Scintigraphic Imaging, Hypoxic Tissue, Clinical Applications, ${ }^{123}$ I-IAZA

\section{INTRODUCTION}

Tissues are hypoxic if molecular oxygen $\left(\mathrm{O}_{2}\right)$ levels are below normal, but not at zero (anoxia). There are substantial fluctuations in $\mathrm{O}_{2}$ levels among and within various tissues under normal perfusion, so that there is no universal base-line criterion for hypoxia. For example, radiobiological hypoxia is most pronounced at $\mathrm{O}_{2}$ levels below $1000 \mathrm{ppm}\left(0.1 \% ;<0.1 \mathrm{~mm} \mathrm{Hg} p \mathrm{O}_{2}\right)$ but in other tissues, metabolic effects may be apparent at $\mathrm{O}_{2}$ concentrations just below the venous blood concentration $\left(<30 \mathrm{~mm} \mathrm{Hg} p \mathrm{O}_{2}\right)$. Hypoxia may develop in tissues because of transient capillary occlusion, vascular or arterial damage, or inadequate angiogenesis. Hypoxia in radiation therapy of cancer is the subject of many reports (Bunn \& Poyton, 1996 Dachs \& Stratford, 1996). A discussion of the causes and pathological implications of hypoxia falls beyond the scope of

\footnotetext{
* Author for correspondence
} 
this review. The oxygen effect in radiation biology refers to the contribution of molecular oxygen $\left(\mathrm{O}_{2}\right)$ to the lethal effects of low linear-energy-transfer (LET) ionizing radiation.

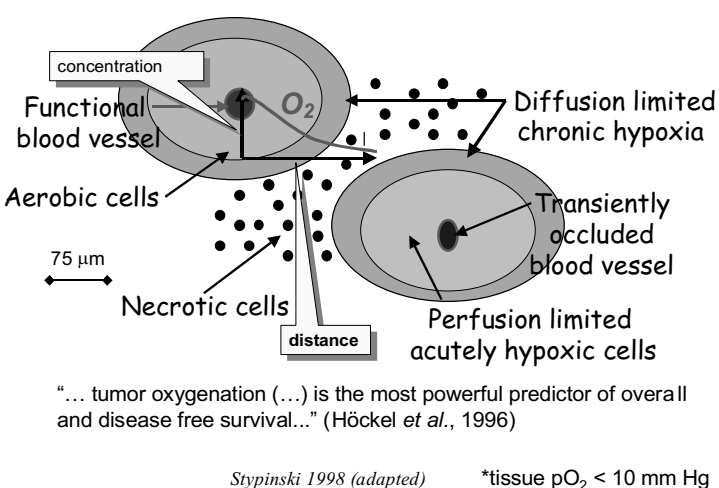

Oxygen-deficient (hypoxic) cells require approximately three times more low -LET radiation for a lethal effect than is required to kill oxygenated cells. This change in sensitivity is referred to as the oxygen enhancement ratio (OER). The OER, which can be up to three (i.e. tissue with $\mathrm{O}_{2}$ is 3 times more sensitive than hypoxic tissue), and is attributable to the reaction of $\mathrm{O}_{2}$ with radiation-induced molecular free radicals. Radiation generates high concentrations of molecular free radicals, hydrated electrons, hydrogen radicals and hydroxy radicals in irradiated tissues. These reactive species, mos tly short-lived and derived primarily from water, react with $\mathrm{O}_{2}$ to produce oxygen radical anion (superoxide), peroxy radicals and other longer lived reactive species that bind co-valently to critical cellular molecules such as DNA, through a process called adduct formation. Adduct formation renders the radiation-induced damage largely irreparable by preventing or inhibiting normal homeostatic repair mechanisms. The physiological implications of this biochemistry are multifaceted (Dachs \& Stratford, 1996).

Some but not all classes of radiosensitizers act by mimicking the oxygen effect (Adams \& Dewey, 1963). The 'oxygen mimetics' form adducts under the reducing conditions found in viable but hypoxic cells, often producing OER's in the $2-3$ range. The reductive binding (adduct formation) of nitroimidazoles (Scheme 1) not only increases the sensitivity of hypoxic cells to low LET ionizing radiation through this oxygen-mimicking process, but also results in their hypoxia-selective accumulation in hypoxic cells.

\begin{tabular}{|l|}
\hline Effects of Hypoxia on Cancer \\
- $\quad$ Radioresistance \\
- Chemoresistance \\
- Receptor upregulation \\
- Anitiation of angiogenesis \\
- Activation of gene sequences \\
\\
\end{tabular}

For radiolabelled nitroimidazoles, this adduct formation in the virtual absence of $\mathrm{O}_{2}$ (hypoxia) is the basis for selective radiotracer accumulation, and imaging, in target tissues. The specificity of adduct formation in only those cells which are hypoxic is attributable to the formation of chemically-reactive species by metabolicallyviable, functional reductases. Importantly, as shown in Scheme 1, the first-electron reduction process is reversible, thereby ensuring that adduct formation will occur primarily in the absence (low concentrations) of $\mathrm{O}_{2}$.

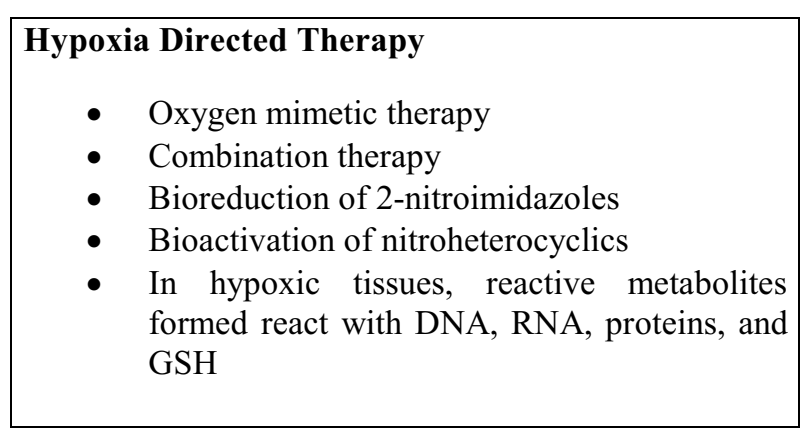

In contrast to the case for radiosensitization in radiotherapy, where reducing equivalents (electrons) may be produced in high flux through the interaction of therapeutic $\mathrm{x}-/ \gamma$-radiation with cell constituents (mainly water), hypoxia -sensitive radiopharmaceuticals must be reduced by metabolically-derived electrons. Flavin-dependent cytochrome P450 reductase and related enzymes, including xanthine and aldehyde oxidases, and quinone oxidase, are capeable of carrying out the activation (reduction to reactive species) step. (Biaglow et al., 1986).

The bioreductive activation process is dependent on the flow of electrons, derived from the intermediary metabolism of glucose, down the electromotive potential of the cytochrome chain. 
The electrons flow from low electron po tential to more electron-affinic species, as depicted in Scheme 2. Normally, $\mathrm{O}_{2}$ is the ultimate electron recipient, but in its absence other molecules can accept and be reduced by these electrons. The cell must be viable, even if oxidatively quiescent, to carry out this function. Indeed it is this property that makes hypoxia valuable therapeutic and diagnostic target, enabling the oncologist to selectively treat the diseased tissues, and the diagnostician to discriminate between dead and potentially salvage able tissue.

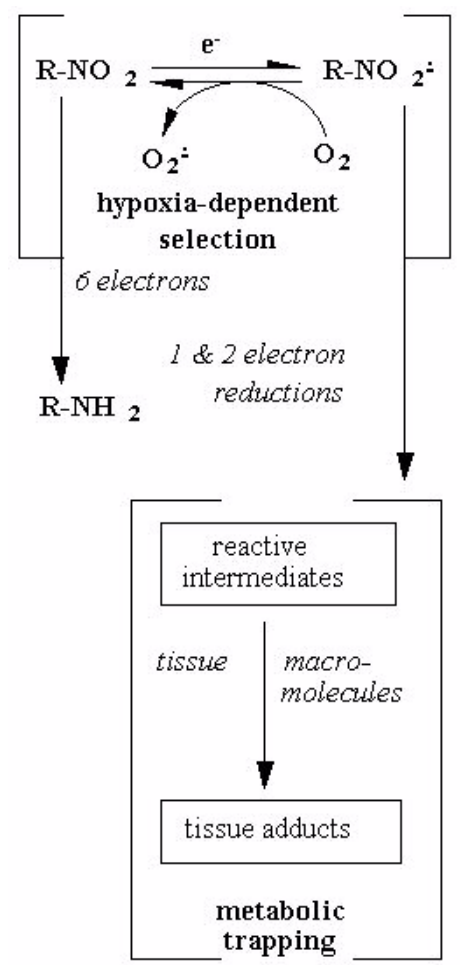

Scheme 1 - Reductive activation and binding of nitroimidazole radiosensitizers (left).

\section{Design considerations for hypoxia radiotracers}

In 1981 Chapman (Chapman et al., 1981) postulated that nitroimidazole radiosensiti zers could form the basis of a useful predictive assay of hypoxia in radiation therapy planning. The design of radiolabelled nitroimidazole radiosensitizers has been based largely on the extensive literature that describes the properties of clinically acc eptable radiosensitizers.

Electron reduction potential $(E)$ and water-lipid partition $(P)$ have been identidied as the critical properties that govern efficacy and toxicity of nitroimidazole radiosensitizers. Briefly, if the electron affinity of the tracer for the first, singleelectron, reduction step (first electron reduction potential at neutral $\left.\mathrm{pH}, \mathrm{E}^{1}{ }_{7}\right)$ is too great, approaching that of $\mathrm{O}_{2}(-155 \mathrm{mV})$, then selectivity for hypoxia will be diminished; if it is not sufficiently electron-affinic $\left(\mathrm{E}_{7}^{1}<-450 \mathrm{mV}\right)$, then sensitivity will be lost. This step is critical, since it is reversible by $\mathrm{O}_{2}$ and is therefore responsible for selective binding to only those tissues that are $\mathrm{O}_{2}$ deficient. The $\mathrm{E}^{1}{ }_{7}$ 's of most 2-nitroimidazoles are around $-390 \mathrm{mV}$, an electron affinity considered to be optimal for both selectivity and sensitivity (Adams et al., 1976).

An equally important property is the radiosensitizer's ability to permeate tissues. The combination of extra- and intracellular water, and hydrophobic cellular membranes, dictates that the molecules must have some lipophilicity (Brown and Workman, 1980). However, if they are too lipophilic (octanol:water $P>10$ ), they will dissolve in lipoidal tissues and delineate areas that are not necessarily hypoxic. Lipophilicity increases the toxicity of these compounds at therapeutic doses, and causes false-positive regional uptake when used in radioimaging (tracer) doses. If they are too hydrophilic $(P<$ 0.1 , they may not diffuse readily through cell membranes or poorly perfused tissue, and they are likely to be cleared very rapidly via the kidney. Both of these lipophilic effects will sharply reduce the amount of drug available for intracellular metabolic activation and hypoxia-dependent binding. The consequence for imaging will be low signal intensity, and for radiotherapy, it will be ineffective delivery of the radiation dose.

Other design properties that must also be considered (Workman and Brown, 1981). Protein binding may affect both clearance and diffusion from the central compartment (blood) to tissues. Strong protein binding of the radiopharmaceutical or any of its radiolabelled metabolites may result in prolonged clearance times, thereby delaying or preventing imaging, or adding unwanted general delivery of the radiation dose because of poor target-to-background selectivity. The route of elimination of the radiotracer and its metabolites is also important, with renal clearance and urinary excretion being preferred over hepato-biliary clearance because of radiation dosime try and imaging complexity considerations. Similarly, metabolism other than reduction will complicate image interpretation or dose-delivery estimation 
because of differences between the radiopharmaceutical and its metabolite(s) with respect to whole-body tracer kinetics, microkinetics (intracellular dynamics) and even metabolic binding. Finally, the acidity (pKa) of the molecule will influence trans-cellular diffusion equilibrium if there are intercellular-extracellularintravascular $\mathrm{pH}$ gradients. Weakly acidic or weakly basic compounds will concentrate as a result of ionization in either extracellular or intracellular fluid, leading to ionic trapping or exclusion, and possibly erroneous estimation of tissue oxygenation or delivery of the radiation dose to non-target tissues.

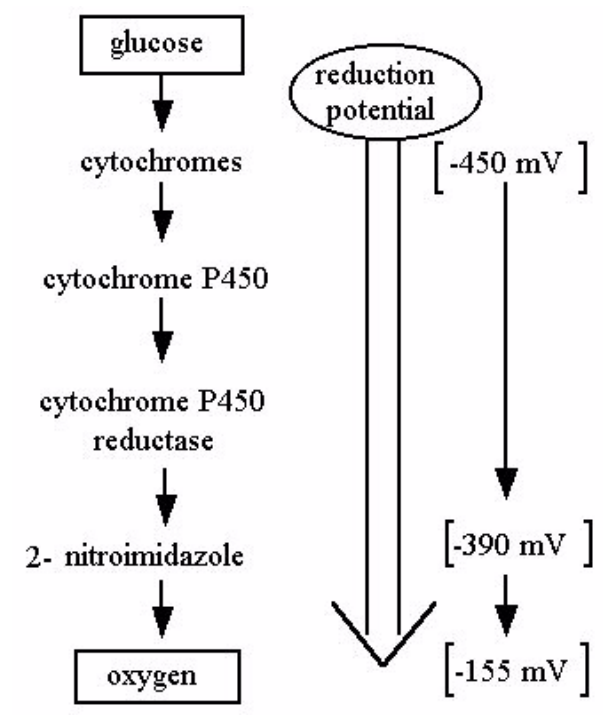

Scheme 2 - Electron flow from glucose to $\mathrm{O} 2$ along the flavin-cytochrome system in metabolically viable tissue (right).

There are also design limitations imposed by the radionuclide to be used as the radiation source. Of the elements represented in most biological compounds ( $\mathrm{H}, \mathrm{C}, \mathrm{N}, \mathrm{O}, \mathrm{P}$ and $\mathrm{S})$, only carbon has a gamma-emission (actually positron annihilation gammas) of suitable energy and a decay half-life for imaging, and $\mathrm{P}$, although having a therapeutically-useable beta emission, is not present in most molecules. Radiohalogens, especially ${ }^{123} \mathrm{I}$ and ${ }^{18} \mathrm{~F}$, have the most acceptable properties for imaging in terms of photon energy, photon flux, decay half-life and radiation dosimetry. Importantly, the chemical propertie s of $\mathrm{I}$ and $\mathrm{F}$ make them acceptable bioisosteric replacements for $\mathrm{H}$, hydroxyl and even methyl substituents (Wiebe, 1984).
Other radiohalogens $\left({ }^{124 / 125 / 131} \mathrm{I} ;{ }^{82} \mathrm{Br}\right)$ and ${ }^{99 \mathrm{~m}} \mathrm{Tc}$, have been proposed for and/or used in the synthesis and pre-clinical evaluation of potential hypoxia radiotracers, with limited success to date. The introduction of these 'non-isotopic radiotracers complicates the design of the hypoxia imaging radiopharmaceutical because they perturbate the physico-chemical properties of the labelled product. For example, replacement of hydroxyl by (radio)iodine at C -5 of an azomycin nucleoside will increase the $\mathrm{P}$ value by almost one order of magnitude (Wiebe et al., 1991).

Interested readers are referred to reviews by Nunn et al. (Nunn and Strauss, 1995), Wiebe and Stypinski (Wiebe and Stypinski, 1996), and Machulla (Machulla, 1999) for detailed information on the development of hypoxiaselective agents.

\section{${ }^{123}$ I-IAZA [azomycin arabinoside; 1- $\alpha$-D-(5-iodo- 5-deoxyarabino-furanosyl)-2-nitroimidazole; IAZA]}

The radioiodinated 2-nitroimidazoles (azomycin derivatives) comprise the main body of literature that deals with agents for single photon (planar or tomographic) scintigraphic detection of tissue hypoxia. Their $\mathrm{E}_{7}^{1}$ 's lie within the range for $\mathrm{O}_{2-}$ reversible reductions to occur, so the main challenge in molecular design is to optimize their metabolic (non-reductive) and pharmacokinetic properties. Misonidazole (Miso) remains the reference compound against which the sensitizing properties of radiosensitizers are compared. Unfortunately, as mentioned in the preceding paragraph, it is not suitable for imaging because it does not contain elements that have a suitable gamma-emitting radioisotope. In our research program, the radiohalogenated azomycin nucleosides were selected because the side-chain hydroxyl groups counteract the lipophilic effects of iodine, thereby forming radiotracers that are only weakly lipophilic. A number of azomycin nucleosides have been reported (Wiebe et al., 1986; Jette et al., 1986; Mercer et al., 1990; Mannan et al., 1991; Mannan et al., 1992; Mannan et al., 1992; Schneider et al., 1997; Kumar et al., 1999). Of these, iodoazomycin arabinoside (IAZA) (Mannan et al., 1991) and iodoazomycin pyranoside (IAZP) (Mannan et al., 1992) have been applied in clinical studies. The development of ${ }^{123}$ I-IAZA, and its clinical applications, are reviewed in the following paragraphs. 


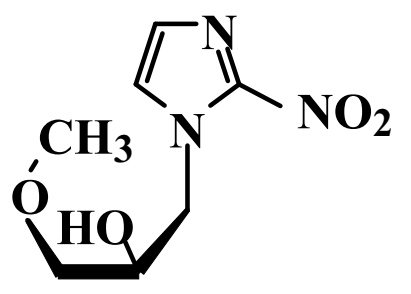

misonidazole

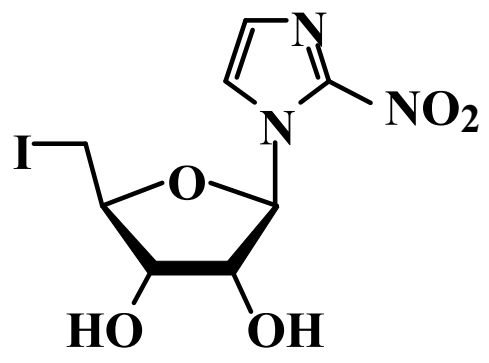

$\beta$-iodoazomycin riboside

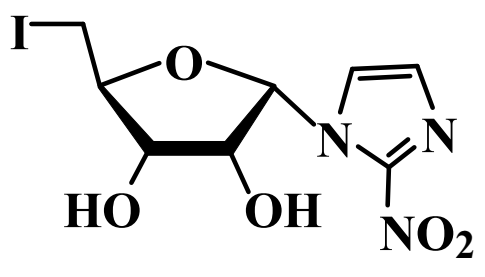

123|-IAZA

\section{Pre-clinical development of IAZA}

The synthesis of 1- $\alpha$-D-(5-iodo-5-deoxyarabinofuranosyl)-2-nitroimidazole (azomycin arabinoside; ${ }^{123}$ I-IAZA) was reported in 1991 (Mannan et al., 1991). ${ }^{123}$ I-IAZA is more lipophilic $(P=4.98)$ than the sensitizer misonidazole $(P=0.41)$ (Brown and Workman, $1980)$, and than azomycin riboside $(P=2.1)$ (Jette et al., 1986), the first reported compound of this class.

${ }^{123}$ I-IAZA was found to undergo in vitro hypoxiadependent adduct formation at a higher rate than misonidazole.

Binding to tissue macromolecules formed non diffusible adducts over a range of oxygen concentrations, with most rapid binding occurring at the lowest oxygen concentrations.

Although it was found to be more effective as a radiosensitizer, it was also more cytotoxic (Mannan et al., 1991). Since toxicity is not a concern at the low chemical doses used in scintigraphic imaging, radioiodinated ${ }^{123}$ I-IAZA was considered highly suitable for imaging applications in diagnostic nuclear medicine and it has been suggested (M. Piert, personal communication) that ${ }^{131}$ I-IAZA may be well-suited for isotope radiotherapy of cancer.

Preclinical biodistribution studies with ${ }^{125 / 123} \mathrm{I}$ IAZA revealed that there was minimal deiodination and metabolic degradation in the in vivo EMT-6 murine tumour model. Scintigrams taken $8 \mathrm{~h}$ post ${ }^{123}$ I-IAZA injection in this model showed strong uptake by the tumour and rapid whole-body background clearance, providing clear images within 4-6 $\mathrm{h}$ after injection. Administration of a 'cold' dose of ${ }^{123}$ I-IAZA several hours after the tracer dose has been shown to reduce blood levels of radioactivity by almost $50 \%$ without reducing hypoxic tumour radioactivity (Mannan et al., 1991). Although this technique is appealing from the dose-distribution vantage, risk associated with administering a relatively large (radiosensitizing) chemical dose would have to be assessed before clinical evaluation of the procedure could proceed. The delineation of thyroid and stomach in the $24 \mathrm{~h}$ scintigrams of mice that were not pre-dosed with iodide to block thyroid uptake at later imaging times confirmed that deiodination, which represented only around $1 \%$ of the dose, would not interfere with imaging; however, in radiotherapy the standard thyroid blocking technique would be applied (Mannan et al., 1991).

Radioiodinated ${ }^{123}$ I-IAZA has been used for imaging in a variety of experimental path ological conditions. In photodynamic therapy (PDT) of cancer using the Fisher $\mathrm{x}$ Copenhagen rat Dunning 3327 prostate tumour model, ${ }^{123}$ I-IAZA localized in regions of PDT-induced hypoxia. Binding of ${ }^{123}$ I-IAZA correlated inversely ${ }^{99 \mathrm{~m}} \mathrm{Tc}-\mathrm{HMPAO}$ uptake (a perfusion marker), to provide physiological evidence in support of ${ }^{123}$ I-IAZA's hypoxia-selective binding (Moore et al., 1993).

A dual radionuclide autoradiographic study of cerebral occlusion in rats depicted uptake of ${ }^{125} \mathrm{I}$ IAZA in ischaemic areas also shown to be mutually exclusive to ${ }^{99 \mathrm{~m}} \mathrm{Tc}-\mathrm{HMPAO}$ perfusion in poorly perfused regions of the brain (Lythgoe et al., 1997). Magnetic resonance imaging studies in this model of brain ischaemia showed that ${ }^{123} \mathrm{I}-$ IAZA binding correlated inversely to the apparent diffusion coefficient for water in the occluded region. These experiments demonstrated that increased binding of ${ }^{125}$ I-IAZA occurred as cerebral blood flow decreased, with a $35 \%$ 
decrease in flow required before any binding increase was observed (Lythgoe et al., 1999).

Preliminary studies in a surgical model of canine myocardial ischaemia showed uptake of ${ }^{123}$ I-IAZA in ex vivo but not in vivo $4 \mathrm{~h}$ after dosing. Tissue analysis reflected good hypoxic binding, but persistent radioactivity in blood at short times (3-4 $\mathrm{h}$ after injection) obscured uptake by hypoxic myocardium (Okada et al.).

${ }^{123} \mathrm{I}$-IAZA and ${ }^{99 \mathrm{~m}} \mathrm{Tc}$-pertechnetate have also been used in models of non-steroidal anti-inflammatory drug (NSAID) damage to the intestinal epithelium and of adjuvant-induced arthritis in rats. These animal models showed abnormal and contrasting biodistribution patterns for both of these tracers (Davies et al., 1996). The NSAID model showed massive accumulation of radioactivity in the peritoneal cavity, whereas the arthritis model showed focal uptake in the affected joint as well as diffuse uptake in the surrounding tissue. The relationships of these biodistribution patterns to hypoxia are not understood, and remain under investigation (Davies et al., 1996).

In murine models, the relatively slow clearance of radioactivity from the blood stream makes it necessary to image at 4 to $8 \mathrm{~h}$ after injection of ${ }^{123}$ I-IAZA. A pharmacokinetic study of ${ }^{125}$ I-IAZA in rats has shown that there are two radioactive (pharmacokinetic) populations in rat plasma. Chromatographically, one component has been characterized as ${ }^{125}$ I-IAZA itself. The second component, chromatographically eluting at the column void volume, appears to include radioiodide and may include other hydrophilic metabolites. The latter are cleared more slowly than ${ }^{125}$ I-IAZA, and are partially responsible for the (slow) clearance of radioactivity from the bloodstream (Stypinski et al., 1997; Stypinski et al., 1999).
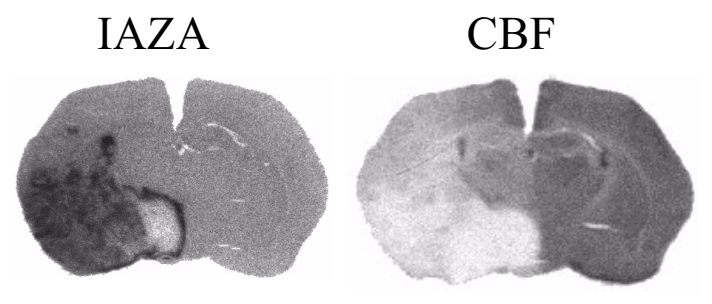

ROIs from IAZA and $\mathrm{CBF}$

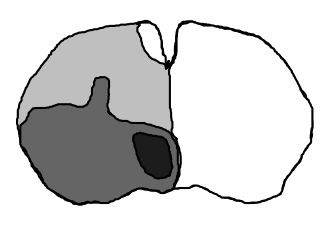

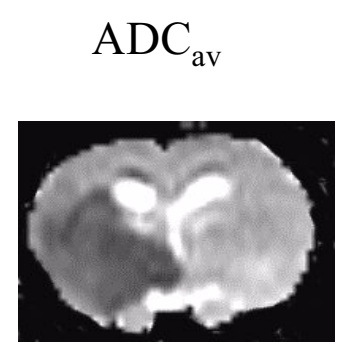

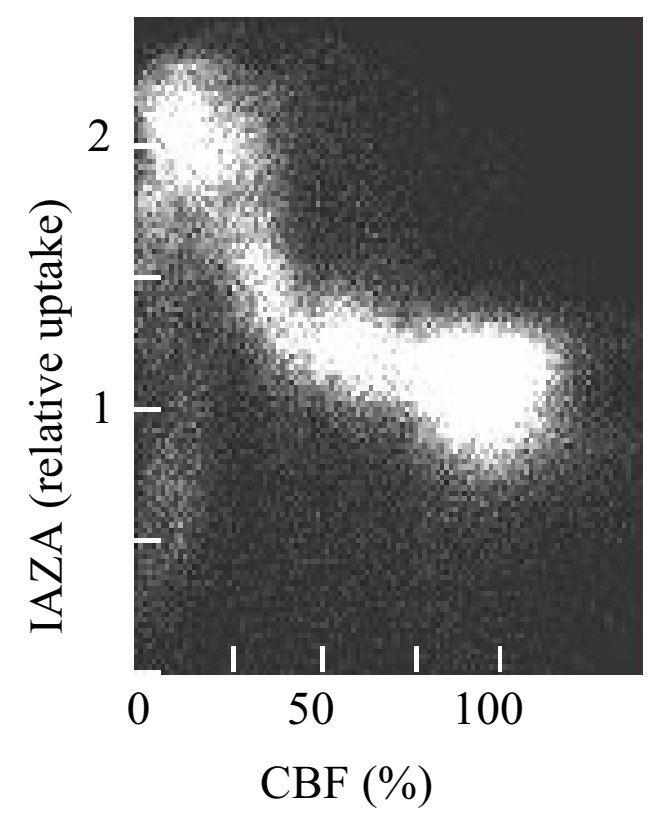

Plate 1 - Autoradiographic distribution in rat brain of ${ }^{125}$ I-IAZA (IAZA) and ${ }^{99 m}$ HMPAO (CBF) alone and in overlay presentation of regions of interest (ROI) from ${ }^{125} \mathrm{I}^{123}{ }^{12} \mathrm{I}-\mathrm{IAZA}$ and $\mathrm{CBF}$, compared to an apparent diffusion coefficient map $\left(\mathrm{ADC}_{\mathrm{av}}\right)$ from magnetic resonance imaging. The graph on the right depicts ${ }^{125}$ I-IAZA binding as a function of CBF. Reproduced and adapted from Lythgoe et al. 1999 (Lythgoe et al., 1999).

The fully reduced amino metabolite (1-[5-iodo-5deoxyarabino-furanosyl]-2-aminoimidazole) (Lee et al., 1999) and the hydrolytic radiolabelled sugar product (5-iodo-5-deoxyarabinofuranose) (Lee et 
al., 2000) have been excluded as contributing metabolites. Anesthesia during imaging has been shown to perturbate the pharmacokinetic profile for ${ }^{125}$ I-IAZA, but not for total radioactivity, in the rat. (Stypinski et al., 1999).

\section{Clinical applications of ${ }^{123}$ I-IAZA}

High diffusibility into poorly-vascularized (ischaemic) tissues, high reductive binding rate, moderately rapid clearance from blood, rapid total body clearance and minimal loss of radiolabel in animal studies provided the rationale for clinical tumour imaging with ${ }^{123}$ I-IAZA. Clinically, ${ }^{123} \mathrm{I}-$ IAZA -based investigations of regional hypoxia have focused on cancer (Parliament et al., 1991), but several other conditions in which hypoxia is known to play a role have als o been examined.

These include diabetes (Al-Arafaj et al., 1994), arthritis (McEwan et al., 1997), brain trauma (Vinjamuri et al., 1999) and exercise-stress (Cwik et al., 1995). In addition, a complete pharmacokinetic (Stypinski et al., 1999) and radiation dosimetric evaluations (Stypinski et al., 2001) of ${ }^{123}$ I-IAZA in healthy human volunteers and in cardiac-stressed human volunteers have been reported. These clinical investigations have been conducted under the auspices of local medical ethics and radiation safety authorizations.

\begin{tabular}{l}
\multicolumn{1}{c|}{${ }^{123}$ I-IAZA in Clinical Hypoxia } \\
- Cancer (\& perfusion correlation) \\
- Peripheral vascular disease (diabetes) \\
- Arthritis \\
- Blunt trauma of brain \\
- Healthy volunteers \\
- Cardiac-stressed healthy volunteers \\
\hline
\end{tabular}

\section{Cancer}

It is understandable, given the role of tumour hypoxia in radiation resistance of some human tumours, that most of the patients studied with ${ }^{123} \mathrm{I}$ IAZA have oncological disease. Of these cancer patients, most presented with head and neck primaries and/or metastases, including small ce 11 lung cancer, squamous cell carcinomas, glioblastomas and soft-tissue sarcoma. About $40 \%$ of the tumours were found to be hypoxic, based on the ${ }^{123}$ I-IAZA-uptake criterion (Parliament et al., 1991).

A correlative study of ${ }^{123}$ I-IAZA uptake (for hypoxia) as a function of tissue perfusion $\left({ }^{99 \mathrm{~m}} \mathrm{TcHMPAO}\right.$ uptake) revealed an inverse relationship between these two markers (correlation $\mathrm{P}=0.05$ ). The uptake criterion was a tumour:background $(\mathrm{T} / \mathrm{N})$ ratio of 1.5 ; the $\mathrm{T} / \mathrm{N}$ averaged 2.3 for small cell lung tumours (SCC) and 1.9 for sarcomas (Groshar et al., 1993).

Avidity for ${ }^{123}$ I-IAZA was also seen in a small sample of patients with breast cancer (McEwan et al.). A small follow-up study of the prognostic potential of hypoxia with respect to radiation therapy response showed that ${ }^{123}$ I-IAZA -avid tumours ( 1 of 4 ) were not controlled 3 months after therapy, whereas non-avid tumours were controlled (7 of 10) (McEwan et al.). This is consistent with accurate diagnosis of hypoxia and its correlation to poor therapeutic control associated with radioresistant tumours.

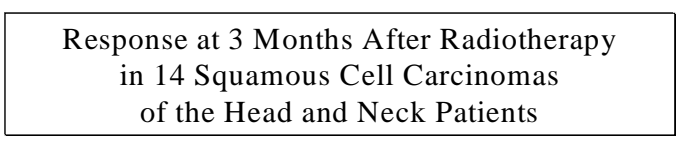

Patients with hypoxic tumors are less likely to have tumor control after radiation therapy:

$\frac{\text { Response }}{\mathrm{CR}} \quad \frac{\text { Avid IAZA }}{1 / 4} \quad \frac{\text { Non-avid IAZA }}{7 / 10}$
$\overline{\text { Urtasun RC, Br J Cancer, 1996; 74: S209 }}$

Late brain uptake (Plate 2) has been observed in the images of approximately $30 \%$ of the cancer patients who received ${ }^{123}$ I-IAZA (McEwan et al.). It is not known whether this phenomen on represents uptake of a radioactive metabolite, or whether it indicates that the integrity of the blood brain barrier has been compromised by active chemo- and radiotherapy. All patients in these studies had received their complete regimen of radiation and chemotherapy. 
Table 1 - Quantitative analysis of tumour type and ${ }^{123}$ I-IAZA avid scans with median tumour/noise signal of 1.47 (range 1.10-1.47), in fifty-two patients.

\begin{tabular}{lcc}
\hline Tumour Classification & ${ }^{123}$ I-IAZA & $\%$ Hypoxic \\
& Uptake $/$ total cases & \\
\hline Small-cell lung cancer & $9 / 15$ & $60 \%$ \\
SCC* of head and neck & $6 / 15$ & $40 \%$ \\
Malignant gliomas & $0 / 11$ & $0 \%$ \\
Brain metastases & $3 / 4$ & $75 \%$ \\
Soft-tissue carcinomas & $3 / 5$ & $60 \%$ \\
Prostate carcinoma & $0 / 1$ & $0 \%$ \\
Melanoma (metastatic to neck) & $0 / 1$ & $0 \%$ \\
Total & $21 / 52$ & $40 \%$ \\
\hline
\end{tabular}

*SCC is small cell carcinoma. Reproduced from Urtasun et al.1996 (36).

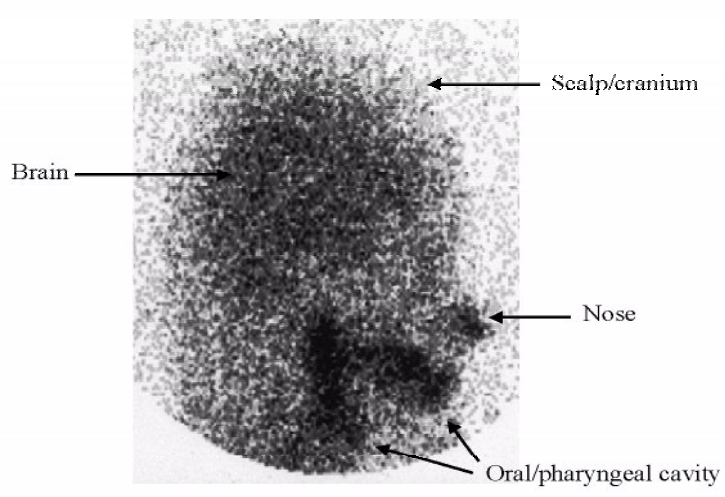

Plate 2 - Accumulation of radioactivity in brain in a planar $24 \mathrm{~h}$ image, following injection of ${ }^{123}$ I-IAZA. Radioactivity in the nose and oral-pharyngeal regions is attributed to radioiodide secretion in saliva.

\section{Peripheral vascular disease}

Diabetes mellitus is a prevalent disease in which the acute symptoms are usually managed by insulin replacement therapy. Chronic disease, even with effective glucose control, is frequently associated with serious complications. Diabetic peripheral vascular disease causes ischaemia, which leads to ulceration, infection and even amputation of affected limbs. Current diagnosis of peripheral vascular complications includes superficial transcutaneous measurement of limb oxygenation $\left(\mathrm{TcpO}_{2}\right)$ using oxygen-sensitive surface electrodes, a technique that does not detect subcutaneous hypoxia and therefore is not effective until ulceration is imminent (Mercer and Liu, 1999).

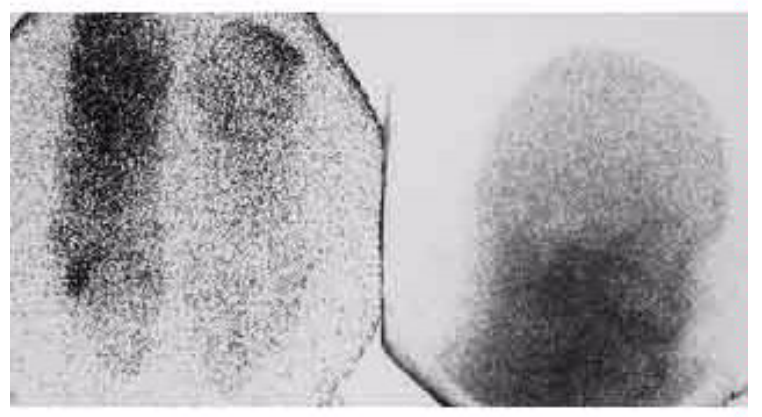

Plate 3 - ${ }^{123}$ I-IAZA scintigraphic images showing focal and diffuse uptake in the feet (left panel), and absence of radioactivity (normal) in the head (right panel), of a diabetic patient.

In an imaging investigation of the lower limbs of diabetic patients, ${ }^{123}$ I-IAZA images depicted both regional and focal hypoxia (Al-Arafaj et al., 1994). Image correlation to $\mathrm{TcpO}_{2}$ scores and visible lesions indicated that ${ }^{123}$ I-IAZA imaging may have a role as a predictive test to identify developing deep pathology that cannot be detected by superficial $\mathrm{TcpO}_{2}$ methods.

\section{Rheumatoid arthritis}

Hypoxia in load-bearing joints results from momentary ischaemia during the pressure interval. Joints with inflammatory effusive synovitis have associated increases in intra-articular pressure. In rheumatoid arthritis, increases in synovial membrane oxygen consumption combine with chronically high intra-articular pressures to create an hypoxic joint. Oxygen measurements in 
synovial tissue biopsies and in aspirated synovial fluid correlate with low $\mathrm{pH}$, increased lactate, elevated $p \mathrm{CO}_{2}$, high intra-articular pressure and large synovial fluid volume. Importantly, oxygen concentrations are inversely related to severity of arthritic disease. The radiopharmaceuticals currently used or proposed for imaging the arthritic joint act non-specifically or are targeted towards other (not hypoxia) specific markers. In an ongoing clinical study using ${ }^{123}$ I-IAZA, scintigraphic evidence (Plate 4) of arthritic joint hypoxia has been observed but intensity of binding does not correlate strongly to severity of disease in these patients (McEwan et al., 1997).

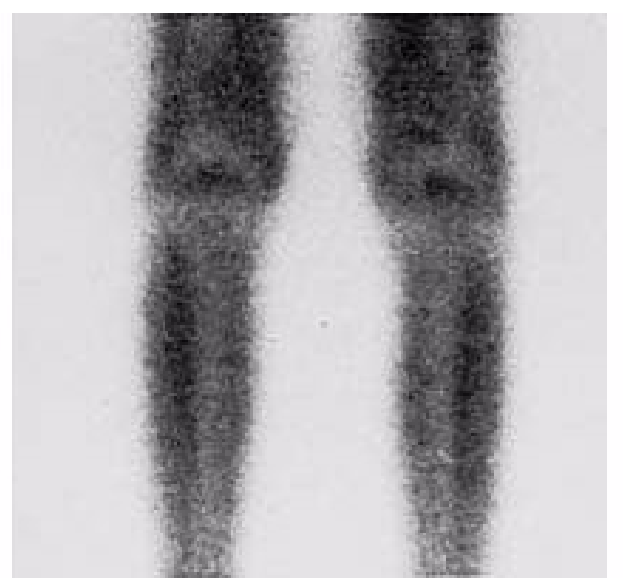

Plate 4 - ${ }^{123}$ I-IAZA scintigram showing focal uptake of radioactivity in the knee joints of a patient with rheumatoid arthritis.

\section{Blunt trauma of brain}

${ }^{123}$ I-IAZA has also being used clinically to study regional hypoxia associated with brain trauma (Vinjamuri et al., 1999). Preliminary data indicate that ${ }^{123}$ I-IAZA uptake occurs in areas in decreased perfusion. There may be a complimentary role for hypoxia imaging to verify the viability of poorly perfused brain tissue, to provide a prognosis for recovery and to reflect therapeutic efficacy.

\section{Pharmacokinetics and dose effects}

In early clinical studies there was some concern chemical dose (amount of substance administered) could affect the sensitivity of this diagnostic imaging test in vivo. A clinical study of tumour binding of ${ }^{3} \mathrm{H}$-Miso was based on a nominal $10 \mathrm{mg}$ dose of radiotracer (Urtasun et al., 1986), reflecting literature reports of dose-dependent Miso pharmacokinetics (Wiebe and Stypinski, 1996). Animal tumour models had also found dose-dependent uptake of ${ }^{123}$ I-IAZA (Mannan et al., 1991). The impact of ${ }^{123}$ I-IAZA dose on uptake in hypoxic tissue has not been systematically investigated in patients.

However, clinical radiopharmacokinetics and radiotracer kinetics in healthy volunteers and patients, after i.v. doses ranging from 0.1 to $10 \mathrm{mg}$ of carrier ${ }^{123}$ I-IAZA, showed no discernible differences in plasma clearance and whole-body elimination (Stypinski et al., 1999). These pharmacokinetic studies in healthy volunteer $\mathrm{s}$ confirmed rapid distribution and clearance phases, with extensive urinary clearance (Plate 5). Images and radiopharmacokinetics in cardiac stressed volunteers (Bruce protocol) were qualitatively and quantitatively similar to the data from resting volunteers (Stypinski et al., 2001). Initial radiation dosimetry estimates indicate a dose of 0.12 $\mathrm{mGy} / \mathrm{MBq}$ to the bladder wall and 10 -fold less to the liver (Stypinski et al., 2001).

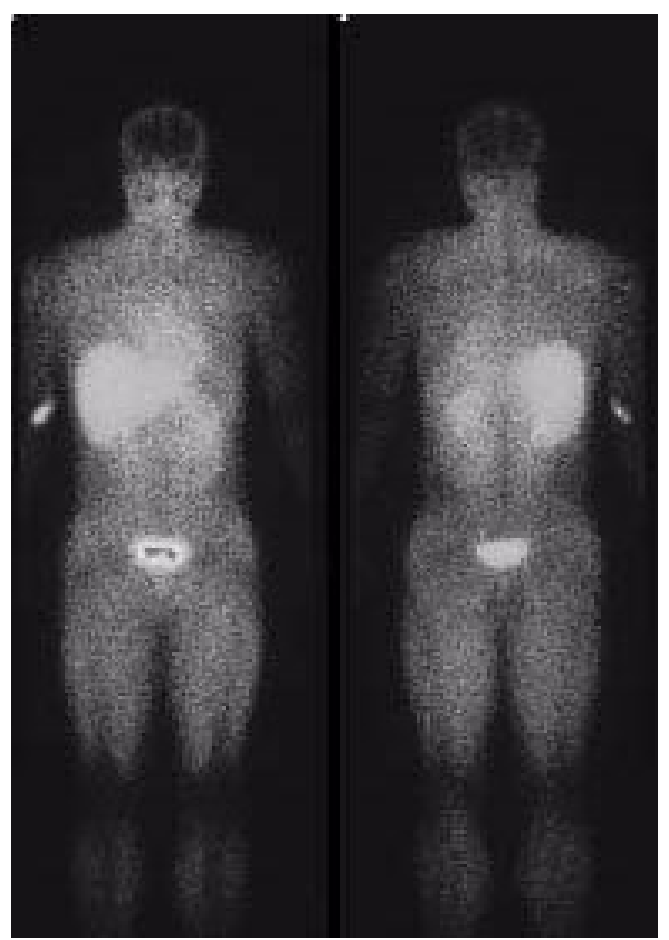

Plate 5 - Planar scintigram of a healthy volunteer $30 \mathrm{~min}$ after injection of ${ }^{123}$ I-IAZA $(185 \mathrm{MBq}$ as bolus i.v. dose). Reproduced from Stypinski 1998.

Overall, the radiation dose estimates compare favorably with published data for other ${ }^{123} \mathrm{I}-$ and 
${ }^{99 \mathrm{~m}}$ Tc-radiopharmaceuticals. These data can be used to estimate the immediate whole-body radiation burden that can be anticipated when using radiotherapeutic doses of ${ }^{125 / 131}$ I-IAZA. The pharmacokinetic parameters for ${ }^{123}$ I-IAZA and total ${ }^{123}$ I-radioactivity were determined in six resting volunteers. These data depict a substantial contribution of 'non- ${ }^{123}$ I-IAZA radioactivity' to the total radioactivity in plasma, and indicate that longer times after injection will provide better signal-to-noise values. None-the-less, because of the $13 \mathrm{~h}$ half-life of ${ }^{123} \mathrm{I}$, substantial photon flux is lost through decay (almost 75\% in $24 \mathrm{~h}$ ), so same day imaging is preferred over $24 \mathrm{~h}$ imaging. Data are presented in Figure 4 and Table 2.

Table 2 - Decay-corrected pharmacokinetic parameters for ${ }^{123}$ I-IAZA and ${ }^{123}$ I-total radioactivity in human volunteers. Data are means \pm S.D., $\mathrm{n}=6$. From Stypinski et al. 1999.

\begin{tabular}{cccccc}
\hline $\begin{array}{c}\text { Radioactivity } \\
\text { in plasma }\end{array}$ & $\begin{array}{c}T_{1 / 2} \alpha \\
(\mathrm{min})\end{array}$ & $\begin{array}{c}T_{1 / 2} \beta \\
\mathrm{min})\end{array}$ & $\begin{array}{c}V_{s s} \\
(\mathrm{~L} / \mathrm{kg})\end{array}$ & $\begin{array}{c}\mathrm{Cl} \\
(\mathrm{mL} / \mathrm{min})\end{array}$ & $\begin{array}{c}\mathrm{Cl} \\
(\mathrm{mL} / \mathrm{min})\end{array}$ \\
\hline${ }^{\text {Total }}{ }^{123} \mathrm{I}$ & $5.1 \pm 3.2$ & $471 \pm 78$ & $0.90 \pm 0.13$ & $93 \pm 15$ & $80 \pm 10$ \\
& & & & & \\
${ }^{123} \mathrm{I}$ I-IAZA & $5.5 \pm 3.9$ & $232 \pm 46$ & $0.88 \pm 0.3$ & $187 \pm 43$ & $29 \pm 5$
\end{tabular}

$\mathrm{T}_{1 / 2} \alpha(\mathrm{min})$ distribution phase; $\mathrm{T}_{1 / 2} \beta(\mathrm{min})$ clearance phase; $\mathrm{V}_{\mathrm{ss}}(\mathrm{L} / \mathrm{kg})$ volume of distribution at steady state; $\mathrm{Cl}_{\mathrm{s}}(\mathrm{mL} / \mathrm{min})$ systemic clearance; $\mathrm{Cl}_{\mathrm{r}}(\mathrm{mL} / \mathrm{min})$ renal clearance.

\section{CONCLUSION}

Hypoxia imaging agents were initially developed for use as predictive markers of radioresistant (hypoxic) tumours. There is now interest in applying this diagnostic procedure not only to detect hypoxic tissues for radiotherapy planning, but also to delineate viable hypoxic tissue in other diseases.

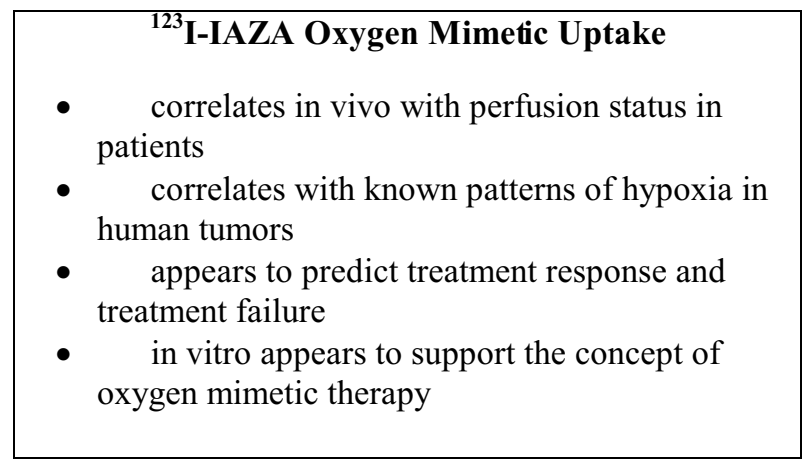

The identification of salvageable hypoxic tissue in a given pathology is important for both prognosis and for monitoring therapy. Demonstrations of the widespread influence of hypoxia on cell biology (Dachs and Stratford, 1996) continue to create interest in hypoxia imaging to address basic scientific questions. As an experimental radiotracer, ${ }^{123}$ I-IAZA has been effective in imaging regional and focal hypoxia in several animal models and in a number of clinical diseases, and in providing validation of the concept that ${ }^{123}$ I-IAZA has a potential role in radioisotope radiotherapy.

It remains necessary to develop a clinical paradigm for validation of the diagnostic efficacy of ${ }^{123}$ I-IAZA in the clinical setting. A postulated model for this evaluation in lung cancer is depicted in the following diagram:

\section{RESUMO}

Os tecidos afetados em inúmeras doenças, incluíndo câncer, acidentes vasculares cerebrais, infarto agudo do miocárdio e diabetes, desenvolvem hipoxia focal tecidual durante a evolução da doença. A presença de tecido hipóxico pode tornar a doença refratária à terapia., como no caso do tratamento de tumores sólidos usando baixa radiação ionizante (LET). Em outras doenças, a detecção de tecidos viáveis mais hipóxicos pode servir como indicador prodômico do desenvolvimento da doença (como por exemplo, diabetes), ou um indicador prognóstico do controle da doença (como no acidente vascular cerebral). Nas últimas duas décadas, vários substâncias utilizadas em radioimagem para avaliar a hipóxia foram desenvolvidas e tes tadas clinicamente. Destas, 18 F-Fmiso e ${ }^{123}$ I-IAZA são os radiotraçadores mais usualmente utilizados para imagens planares de PET e SPECT, 
respectivamente. IAZA e Fmiso são 2 nitroimidazóis que quimicamente se ligam a componentes subcelulares de tecidos hip óxicos viáveis. Eles sensibilizam tumores hipóxicos aos efeitos letais da radiação ionizante via mecanismos que mimetizam os efeitos radiosensíveis do oxigênio, e são consequentemente denominados de oxigênio-miméticos. O efeito oxigênio-mimético é atribuído em grande parte à ligação covalente dos intermediários nitroimidazóis redutivamente ativados paara macromoléculas celulares críticas. Nitroimidazóis marcados com radionuclídeos emissores de radiação gama (por exemplo, $18 \mathrm{~F}$ Fmiso e ${ }^{123}$ I-IAZA) tem sido usado como marcadores cintigráficos da hipóxia tumoral, baseado na necessidade de identificar células tumorais hipóxicas radioresistentes como parte do processo de planejamento da radioterapia. Um interesse mais amplo em identificação não invasiva baseada em imagem de hipóxia focal de várias doenças tem estendido os estudos de hipóxia para incluir doenças vasculares periféricas associadas com diabetes, artrite reumatóide, acidentes vasculares cerebrais, isquemia miocárdica, traumatismo encefálico e estresse oxidativo. Nesta revisão, o estado atual dos estudos de hipoxia seletiva com ${ }^{123}$ I-IAZA, um radiofarmáco para o diagnóstico experimental é revisto em relação ao desenvolvimento de aplicações clinicas e pré-clinicas.

\section{Possible Role of ${ }^{123}$ IAZA in Lung Cancer}

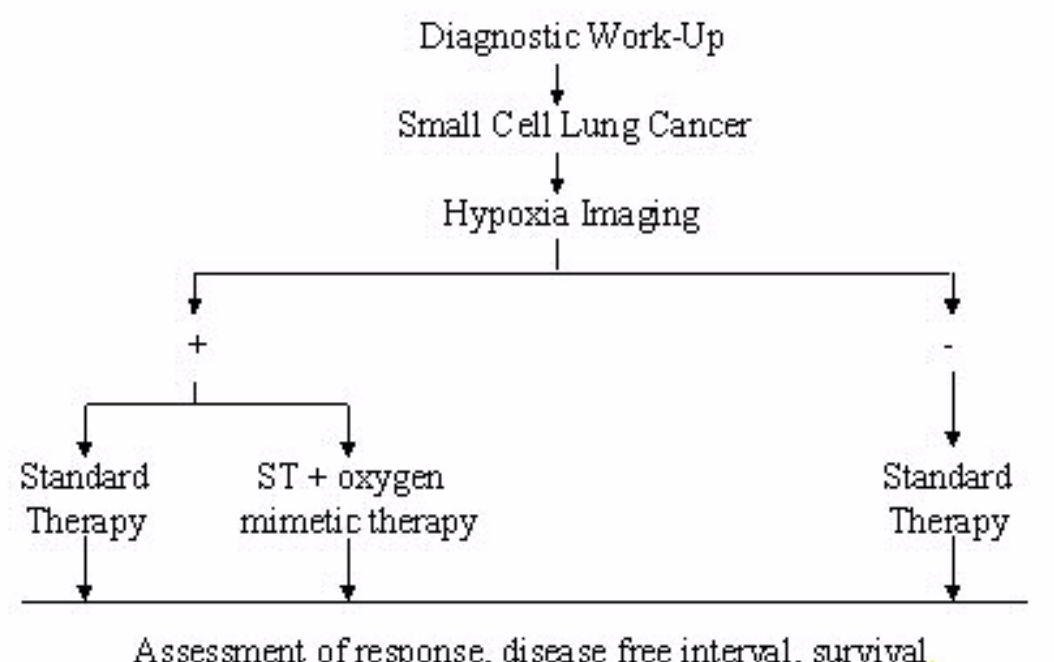

\section{REFERENCES}

Adams, G. E. and Dewey, D. L. (1963), Hydrated electrons and radiobiological sensitization. Biochem. Biophys. Res. Commun., 12, 473-477.

Adams, G. E.; Flockhart, I. R.; Smithen, C. E.; Stratford, I. J.; Wardman, P. and Watts, M.E. (1976), Electron affinic sensitization VIII. A correlation between structure, one electron reduction potential and efficiency of nitroimidazoles as hypoxic cell radiosensitizers. Radiat. Res., 67, 9-20.
Al-Arafaj, A.; Ryan, E. A.; Hutchinson, K.; Mannan, R. H.; Mercer, J.; Wiebe, L. I. and McEwan, A. J. B. (1994), An Evaluation of ${ }^{123}$ I-Iodoazomycinarabinoside ([ ${ }^{123}$ I]-IAZA) as a Marker of Localized Tissue Hypoxia in Patients with Diabetes Mellitus. Europ. J. Nucl. Med., 21, 1338-1442.

Biaglow, J. E.; Varnes, M. E.; Roizen-Towle, L.; Clark, E. P.; Epp, E. R.; Astor, M. B. and Hall, E. J. (1986), Biochemistry of reduction of nitroimidazoles. Biochem. Pharmac., 35, 77-90. 
Brown, J. M. and Workman, P. (1980), Partition coefficients as a guide to the development of radiosensitizers which are less toxic than misonidazole. Radiat. Res., 82, 171-190.

Bunn, H. F. and Poyton, R. O. (1996), Oxygen sensing and molecular adaptation to hypoxia. Physiol. Rev., 76, 839-885.

Chapman, J. D.; Franko, A. J. and Sharplin, J. (1981), A marker for hypoxic cells in tumours with clinical applicability. Brit. J. Cancer, 43, 546-550.

Cwik, V. A.; McEwan A. J. B. and Brooke, M. H. (1995), A novel SPECT method for detecting free radicals in the working forearm. Neurology, 45 : (Suppl. 4), A446.

Dachs, G. U. and Stratford, I. J. (1996), The molecular response of mammalian cells to hypoxia and the potential for exploitation in cancer therapy. $\mathrm{Br} . J$. Cancer, 74, S126-S132.

Groshar, D.; McEwan, A. J. B.; Parliament, M. B.; Urtasun, R.; Golberg, C. L. E.; Hoskinson, M.; Mercer, J. M.; Mannan, R. H.; Wiebe; L. I. and Chapman, J. D. (1993), Imaging Tumor Hypoxia and Tumor Perfusion. J. Nucl. Med., 34, 885-888.

Jette, D. C.; Wiebe, L. I.; Flanagan, R. J.; Lee, J. and Chapman, J. D. (1986), Iodoazomycin Riboside [1(5'-I o d o -5' -d e o x y -r i b o f u r a n o s y $1-2$ nitroimidazole], a Hypoxic Cell Marker. I. Synthesis and in vivo Characterization. Rad. Res., 105, 169-179.

Kumar, P.; Stypinski, D.; Xia, H.; McEwan, A. J. B.; Machulla, H. J. and Wiebe, L. I. (1999), Fluoroazomycin arabinoside (FAZA): Synthesis, $2 \mathrm{H}$ and 3 H-labelling and preliminary biological evaluation of a novel 2-nitroimidazole marker of tissue hypoxia. J. Label. Comp. Radiopharmaceuticals, 42, 3-16.

Lee, H. C.; Kumar, P.; McEwan, A. J.; Wiebe L. I. and Mercer, J. R. (2000), Synthesis, Radiolabelling and Biodistribution of Putative Metabolites of Iodoazomycin Arabinoside. Nucl. Biol. Med., 27, 61-68.

Lee, H. C.; Kumar, P.; Wiebe, L. I.; McDonald, R.; Mercer, J. R.; Ohkura, K. and Seki, K. I (1999), Synthesis of iodoaminoimidazole arabinoside (IAIA): a potential reductive metabolite of the SPECT imaging agent, iodoazomycin arabinoside (IAZA). Nucleosides and Nucleotides, 18, 1995-2016.

Lythgoe, M. F.; Williams, S. R.; Busza, A. L.; Wiebe, L.; McEwan, A. J. B.; Gadian, D. G. and Gordon, I. (1999), The relationship between magnetic resonance diffusion imaging and autoradiographic markers of cerebral blood flow and hypoxia in an animal stroke model. Mag. Res. Med., 41,706-714.

Lythgoe, M. F.; Williams, S. R.; Wiebe, L. I.; McEwan, A. J. B. and Gordon, I. (1997), Autoradiographic imaging of cerebral ischaemia using a combination of blood flow and hypoxic markers in an animal model. Europ. J. Nucl. Med., 24, 16-20.
Machulla, H. J. (1999), Imaging of Hypoxia -Tracer Developments. Kluwer Academic Publishers, Dordrecht.

Mannan, R. H.; Mercer, J. R. and Wiebe, L. I. (1991), Novel non-invasive markers of tumor hypoxia. Ph. $D$. Thesis, University of Alberta. [unpublished].

Mannan, R. H.; Mercer, J. R.; Wiebe, L. I.; Kumar, P.; Somayaji, V. V. and Chapman, J. D. (1992), Radioiodinated Azomycin Pyranoside (IAZP): A Novel Non-Invasive Marker for the Assessment of Tumor Hypoxia. J. Nucl. Biol. Med., 36, 60-67.

Mannan, R. H.; Mercer, J. R.; Wiebe, L. I.; Somayaji, V. V. and Chapman, J. D. (1992), Radioiodinated 12-(Fluoro-4-Iodo-2,4-Dideoxy-b-L-Xylopyranosyl)2-Nitroimidazole: A Novel Probe for the NonInvasive Assessment of Tumor Hypoxia. Rad. Res., 132, 368-374.

Mannan, R. H.; Somayaji, V. V.; Lee, J.; Mercer, J. R.; Chapman, J. D. and Wiebe, L. I. (1991), Radioiodinated 1-(5-Iodo-5-deoxy-b-Darabinofuranosyl)-2- nitroimidazole (Iodoazomycin Arabinoside: IAZA), a Novel Marker of Tissue Hypoxia. J. Nucl. Med., 32, 1764-1770.

McEwan, A. J. B. (1999), Effects of methoxyflurane anesthesia on the pharmacokinetics of 125 I-IAZA in Sprague-Dawley rats. Nucl. Med. Biol., 26, 659-665.

McEwan, A. J. B.; Skeith, K. J.; Mannan, R. H.; Davies, N.; Jamali, F. and Wiebe, L. I. (1996), Hypoxia-Targeted ${ }^{123}$ I-Iodoazomycin Arabinoside Imaging of the Adjuvant Arthritis Rat Model. Can. Assoc. Nucl. Med. Ann. Sci. Mtg., Quebec. [unpublished].

McEwan, A. J. B.; Skeith, K. J.; Mannan, R. H.; Davies, N.; Jamali, F.; Schmidt, R.; Golberg, L. and Wiebe, L. I. (1997), J. Nucl. Med., 38, 300-301.

McEwan, A. J. B.; Urtasun, R. C.; Parliament, M. B.; Mercer, J. R. and Liu, H. (1999), The evaluation of hypoxia in diabetes. In- Machulla, H. J. (Ed.). Imaging of Hypoxia. Tracer Developments. Kluwer Academic Press, Dordrecht. pp. 129-153. [unpublished].

Mercer, J. R.; Mannan, R. H.; Somayaji, V. V.; Lee, J.; Chapman, J. D. and Wiebe, L. I. (1990), Sugarcoupled 2- nitroimidazoles: novel in vivo markers for hypoxic tumor tissue. In- Maddalena, D. J.; Snowdon, G. M. and Boniface, G. R. (Eds.). Advances in Radiopharmacology Wollongong University Printing Services, Australia. pp. 104-113.

Moore, R. B.; Chapman, J. D.; Mercer, J. R.; Mannan, R. H.; Wiebe, L. I.; McEwan, A. J. and McPhee, M. S. (1993), Measurement of PDT-Induced Hypoxia in Dunning Prostate Tumors by ${ }^{123}$ I-Iodoazomycin Arabinoside. J. Nucl. Med., 34, 405-413.

Nunn, A.; Linder, K. and Strauss, H. W. (1995), Nitroimidazoles and imaging hypoxia. Europ. J. Nucl. Med., 22, 265-280. 
Okada, R.; Johnson, G.; Edwards, B.; Mannan, R. H.; McEwan, A. J. B.; Wiebe, L. I.; Davies, N. M.; Mannan, R.; Skeith, K. J.; Jamali, F. and Wiebe, L. I.. (1996), Non-invasive detection of NSAID-induced gastrointestinal damage in the rat: permeability and ischemia probes. Can. Digestive Disease Week. [unpublished].

Parliament, M. B.; Chapman, J. D.; Urtasun, R. C.; McEwan, A. J.; Golberg, L.; Mercer, J. R.; Mannan, R. H. and Wiebe, L. I.. (1991), Non-invasive Assessment of Human Tumour Hypoxia with ${ }^{123} \mathrm{I}-$ Iodoazomycin Arabinoside: Preliminary Report of a Clinical Study. Br. J. Radiol., 65, 90-95.

Schneider, R. F.; Engelhardt, E. L.; Stobbe, C. C.; Fenning, M. C. and Chapman, J. D. (1997), The synthesis and radiolabeling of novel markers of tissue hypoxia of the iodinated azomycin nucleoside class. J. Label. Comp. Radiopharmaceuticals, 39, 541-557.

Stypinski, D.; McQuarrie, S. A.; Wiebe, L. I.; Tan, Y. K.; Mercer, J. R. and McEwan, A. J. B. (2001), Pharmacokinetic Validation of Scintigraphic Dosimetry Estimations for ${ }^{123}$ I-IAZA in Healthy Subjects. J. Nucl. Med., 42, 1418-1423.

Stypinski, D.; Wiebe, L. I. and Mercer, J. R. (1997), A rapid and simple assay to determine the blood and urine concentrations of $1-\left(5-\left[^{123} / 1^{125}\right.\right.$ I] iodo-5deoxyarabinofuranosyl)-2-nitroimidazole, a hypoxic cell marker. J. Pharm. Biomed. Analysis, 16, 1067-1073.

Stypinski, D.; Wiebe, L. I.; McEwan, A. J.; Schmidt, R. P.; Tan, Y. K. and Mercer, J. R. (1999), Clinical pharmacokinetics of ${ }^{123}$ I-IAZA in healthy volunteers. Nucl. Med. Commun., 20, 559-567.

Urtasun, R. C.; Koch, C. J. and Franko, J.A. (1986), Raleigh and J.D. Chapman. A novel technique for measuring human tissue pO 2 at the cellular level. $\mathrm{Br}$. J. Cancer, 54, 2441-2449.

Urtasun, R. C.; Parliament, M. B.; McEwan, A. J.; Mercer, J. R.; Mannan, R. H.; Wiebe, L. I.; Morin, C. and Chapman, J. D. (1996), Measurement of hypoxia in human tumours by non-invasive SPECT imaging of azomycin arabinoside. Br. J. Cancer, 74, S209-S212.
Vinjamuri, S.; O’Driscol, K.; Maltby, P.; McEwan, A. J.; Wiebe, L. I. and Critchley, M. (1999), Identification of hypoxic regions in traumatic brain injury. Clin. Nucl. Med., 24, 891-892.

Wiebe, L. I. (1984), Radionuclides, Radiotracers and Radiopharmaceuticals for in vivo Diagnosis. Radiat. Phys. Chem., 24, 365-372.

Wiebe, L. I. and Stypinski, D. (1996), Pharmacokinetics of SPECT radiopharmaceuticals for imaging hypoxic tissues. Quart. J. Nucl. Med., 39, 270-284.

Wiebe, L. I.; Jette, D. C.; Chapman, J. D.; Flanagan, R. J. and Meeker, B. E. (1986), Iodoazomycin Riboside [1-(5'-iodo-5'-deoxyribofuranosyl-2'-

nitroimidazole], a Hypoxic Cell Marker. II. In vivo Evaluation in Experimental Tumors. Nuclear Medicine in Clinical Oncology. (C. Winkler, Ed.) Springer-Verlag, 402-407.

Wiebe, L. I.; Mannan, R. H.; Mercer, J. R.; Haverland, G. W. and Chapman, J. D. (1991), Structure-Activity Relationships Among Nitroimidazole Nucleosides Used as Markers of Tissue Hypoxia. 7 th Int. Symp. Radiopharmacol.

Workman, P. and Brown, J.M. (1981), Structurepharmacokinetic relationships for misonidazole analogues in mice. Cancer Chemother. Pharmacol., 6, 39-49.
Received: July 14, 2002; Revised: July 17, 2002; Accepted: July 19, 2002. 